\title{
WhatsApp Business Application as a Digital Marketing Strategy of UMKM
}

\author{
Asmayanti ${ }^{1, *}$ Agus Syam ${ }^{2}$, Muhammad Alfa Sikar ${ }^{3}$ Beche Bt Mamma ${ }^{4}$ Sudarmi ${ }^{5,}$ \\ Nurafni Oktaviyah ${ }^{6}$
}

${ }^{1}$ Universitas Negeri Makassar, Indonesia

${ }^{2}$ Universitas Negeri Makassar, Indonesia

${ }^{3}$ Universitas Negeri Makassar, Indonesia

${ }^{4}$ Universitas Bosowa, Indonesia

${ }^{5}$ STIM Lasharan Jaya Makassar, Indonesia

${ }^{6}$ Universitas Negeri Makassar, Indonesia

Email: asmayanti@unm.ac.id

\begin{abstract}
Small and Medium Enterprises (UMKM) are the real sector that accounts for $99.9 \%$ of all businesses operating in Indonesia and absorbs $97 \%$ of the total workforce. The growth of UMKM certainly requires a marketing strategy in the face of business competition. The application Whatsapp Business is functional design platform to help business people manage customer service. There are 5 (five) main features of Whatsapp Business that can help optimeze UMKM development; (1) a catalog for a gallery of products offered, (2) a cart for costumers when they like a product that can be included as a list of items of interest, (3) an automatic massage prepared to provide a quick response as a greeting to new cutomers, (4) quick reply to save message formats for frequently asked questions and (5) labels to mark messages for easy locating. In Indonesia, there are around 6 million users who have accessed Whatsapp Business every month since 2018. This is an opportunity for UMKM to develop their business.
\end{abstract}

Keywords: Whatsapp Business, Digital Marketing, UMKM.

\section{INTRODUCTION}

National economic growth is primarily defined by regional economic development, while small and medium-sized economic activities commonly back the regional economy. According to the Indonesian Ministry of Cooperatives and MSMEs, micro, small and medium enterprises (MSMEs) account for $99.9 \%$ of all companies operating in Indonesia and $97 \%$ of the total workforce. Business units that fall into micro, small and medium enterprises (MSMEs) are crucial for regional and national economic development [1]. The MSME business sector is a sector that is determined when the peak season of economic turmoil. Moreover, it is anticipated to play an essential role in providing employment opportunities to reduce unemployment and play an important role in Indonesia's economic development.

The advancement of technology has forced MSMEs to do business hustles while skilling up their digital capabilities, including aspects of digital marketing. According to BPS, eight million MSMEs were connected to the digital ecosystem in the 8 years before the COVID-19 pandemic. The indication of the principal value was identified during the pandemic. Until May 2021, it peaked at 13.5 million. On the one hand, the information about the needs of prospected consumers can be gathered from digital marketing [2].

Moreover, potential consumers can also find and receive information about products by simply browsing the virtual world to facilitate the search process. Shoppers are now more independent in making purchasing decisions based on search results. Digital marketing can reach everyone, wherever they are, without geographic or time restrictions [3].

According to 2019 BPS data, as of January 2019, it is indicated that in Indonesia, $93 \%$ of internet users search for goods or services online, $90 \%$ of users use various devices to access online stores, and $86 \%$ of users use various devices (laptops and mobile phones). 
telephone) Conduct online transactions). $37 \%$ of users make transactions via PC or laptops, and $76 \%$ of users do online transactions via smartphone devices. The explanation above shows that Indonesia's online shopping expectation is fruitful, where there is a need to harmonize it with the expectation of the prospective customers in digital marketing. Potential customers have used social media or social networks to do online shopping. Social networks have differences. For example, Facebook is used to gain more friends; Instagram is for artistic self-value; Line is for marketing; and Linkedin is for more professional networking. In comparison, email is usually used to send documents and big files. However, it can be seen that business people prefer to use personal websites [4].

One of the US digital marketing agencies, We Are Social, has released data as of January 2017, Youtube (49\%) has been crowned as the most popular social media. The second is Facebook (48\%). Rank three was Instagram (39\%), followed by Twitter (38\%). While Whatsapp (38\%) was at the fifth, and the sixth was Google (36\%). Other social media platforms such as FB Messenger, Line, Linkedin, BBM, Pinterest, and WeChat had average values [5].

Whatsapp has been a well-known application for communication and sending messages. Argues that social media encouraged people to interact with each other through the communities they created in those applications [6]. In addition, Whatsapp provides a digital Business platform for buyers and sellers to interact and share trusted information about the products and the companies, which sellers and buyers benefit from. In Indonesia, around 6 million users have had access to WhatsApp Business every month since 2018. UMKM can use this massive digital platform growth to expand its networking.

\section{THEORETICAL BASIC}

\subsection{Whatsapp Business}

Whatsapp Business is a free downloadable application specially designed for micro business owners. Whatsapp business also comes with features including a business profile which allows users to add important information such as an address, opening hours, business description, email address, and website. Through this application, business communication can run smoothly and comfortably with [7].

Whatsapp business has drawbacks and benefits. The benefits are: 1) WhatsApp Business is designed as a business platform. 2) it has automatic panel response; 3) it helps to reply faster; 4) every message has attached level; 5) it provides a tool to analyze interaction sending by buyers, 6) Company/office number can be used. While the drawbacks of the WhatsApp Business application are: 1) business account's name is permanent. Therefore, it is non-changeable 2) Data security is weak. 3) You cannot use different mobile numbers; 4) Fixed mobile number is used [7].

\subsection{Digital Marketing}

Digital marketing emphasizes the availability of the internet connection, which can bridge interaction between buyers and sellers [8].

Digital marketing supports sellers to expand the marketing of their products by maximizing the use of social media. Consequently, sellers can reduce the expenditure fee and double the profits. Moreover, social media can send all forms of communication such as audio, images, and text to the sellers and buyers and the broader customers [9].

Digital marketing transcends spaces. Compared to conventional marketing, it is superior. This context is supported [10] research finding. They found that online marketing influences customer preferences towards goods and services.

\subsection{Small and Medium Entreprises (UMKM)}

The Business World is operated in and registered in Indonesia. It is included micro, small, medium, and large businesses.

In the 1945 Constitution and TAP MPR NO. XVI/MPRRI/1998, Stating about Economic Politics in the Context of Economic Democracy; people's economy needs to be empowered by the Small and Medium Enterprises. These SMEs could help strengthen the role and potential of the people's economic structure, creating a prosperous, wealthy, and just national economy. Furthermore, in Law Number 9 of 1999, the UMKM definition is stated clearly. However, it was changed to Law Number 20 Article 1 of 2008 concerning Micro, Small and Medium Enterprises because of certain turbulence conditions. The definition of UMKM is as follows:

\subsubsection{Micro Enterprises}

Micro Enterprises, as regulated in this Law, are owned by individual enterprises and/or individual businesses included in the micro-enterprises criteria.

Standards for micro-enterprises are i. Net worth is about Rp. 50,000,000.00 (50 million rupiahs), buildings for business premises is not counted; or ii. Annual sales can be up to Rp.300,000,000.00 (300 million rupiahs). 


\subsubsection{Small Enterprises}

Small Business is operated by individual enterprises or legal entities, which cannot be categorized as a substitute or a company branch. That is directly or indirectly owned or controlled by a company or becomes part of a large company that includes the indicators of a small business, which the meaning is stated in the law.

Small business standards are: i. net worth is exceeded of Rp. 50,000,000.00 (50 million rupiahs), its profit can reach a maximum of Rp. 500,000,000.00 (500 million rupiahs), land and buildings for business premises is not included; or ii. Annual sales exceeded Rp.300,000,000.00 (300 million rupiah), can reach Rp.2,500,000,000.00 (Rp2.5 billion).

\subsubsection{Medium Enterprises}

An individual or group of people owns medium Enterprises. This kind of business is operated by a person or people that are part of the core circle of the business. Usually, it owns medium income and can generate more profit. However, it is also bounded by the law.

Medium-sized enterprises standards are: i. net worth is exceeded Rp. 500,000,000.00 (500 million Indonesian rupiah). It can reach 10,000,000.00 (ten billion rupiah), land and buildings for business are not included, or ii. annual sales exceed Rp.2,500,000,000.00 (Rp2.5 billion). It can be to Rp.50,000,000,000.00 (Rp5 billion).

\subsubsection{Large Enterprises}

States manages large Enterprises, national private business, Joint venture, cooperated foreign business in Indonesia. The income is higher than the medium enterprises.

Large enterprises standards are: i. net worth is exceeded minimum Rp. 500,000,000.00 (500 million Indonesian rupiah). It can be to minimum Rp.50,000,000,000.00 (Rp5 billion).

\section{METHOD}

This research is a qualitative study that uses a literature review that focuses on explaining the study's results.

\section{DISCUSSION}

The advancement of technology has influenced all aspects of human life. The business world has been dramatically affected by the so-called Digital-based marketing, which assists sellers in attracting more potential buyers. This marketing based-digital provides options and alternatives for customers, expands business networking, promotes products, attracts more consumers, increases the value of products sold, and significantly increases income. Digital Marketing provides all information buyers need regarding products and can persuade them to do online transactions via the internet. Buyers also can monitor and search whatever they want regardless of time and geographical restrictions. Digital marketing is a two-way communication that can lead to public awareness and engagement with certain products and brands.

The WhatsApp messaging application users continue to grow as people's daily lives are increasingly dependent on digital connectivity.

As a digital marketing application, WhatsApp business is designed explicitly for micro-businesses to make it easier to communicate with customers.

\subsection{Steps to Create Account}

The following are the steps to create an online business account using the WhatsApp Business application, namely:

- Download the WhatsApp Business application via the Google Play Store, then install in the right corner that says install.

- If it is already installed, open the WhatsApp Business application, agree, and continue at the green bottom center.

- Enter the phone number you want to use for WhatsApp Business and press Continue in the green bottom center. Then you can use WhatsApp Business

- Go to WhatsApp Business settings or settings.

- Go to Business Settings.

- Enter the catalog menu.

- Press the plus sign at the below right corner to get a new product.

- When the Add Product opens, write the product data.

- Press the Done button to save. You can also sell online using WhatsApp Business.

\subsection{WhatsApp Business Features}

\subsubsection{Catalog}

This feature creates a menu gallery that can display products and services for easy selection by customers and online shoppers. This concept helps businesses 
deliver products and makes it easier for customers to find the products they need.

WhatsApp recently updated this feature, allowing businesses to create and manage catalogs on their computers. Companies can also hide out-of-stock items from their catalogs. You can access this feature update from the web or desktop version of WhatsApp Business.

\subsubsection{Cart}

When customers like an item, they can directly add the item to their shopping cart and process the order by chatting with the business owner. When the business account owner activates the catalog function, the shopping cart function is automatically available. The customer can add the selected item to the shopping cart, and then the seller can continue his order to the transaction stage.

\subsubsection{Auto Messages}

When a seller cannot reply to a customer's message, this feature can set up an auto-reply message to know when to reply. Sellers can also create greetings to introduce their business to new customers. Automated messages ensure that sellers reply to customers anytime, anywhere. This feature is essential for business people who have jet lag customers abroad.

\subsubsection{Quick Replies}

Quick Reply allows merchants to save and reuse message formats to answer common questions quickly. How to activate it on Android, click "More Options," then select "Business features" and "Quick reply." Quick response saves a lot of time and helps customers respond quickly.

\subsubsection{Label}

This feature is designed to manage contacts and chats so salespeople can find them faster. Using shortcuts on Android, press and hold a message, select a shortcut, add a shortcut, or create a new shortcut. To find messages with shortcuts, on the chat screen, tap More options, select Shortcuts, and then select the shortcut you're looking for. Labels on WhatsApp Business. This feature helps manage incoming chats and can categorize questions from new or existing customers.

\section{CONCLUSION}

The existence of the UMKM actors can harmonize changes in marketing behavior from traditional to digital. They use online platforms that can encourage the growth of Indonesia's economic sectors. Digital marketing is expected to posit MSMEs into the centers of economic power. Social media is a means of digital technology, especially digital marketing. Moreover, no technical and advanced skills are needed to operate this social media. Therefore, it can be used by all people and reach potential buyers in real-time. The illiteracy of MSME actors in digital marketing can cause problems, and these problems need to be overcome as the improved situation can help sellers promote their products. Understanding the importance of digital marketing for the development of their business can motivate them to learn more about digital marketing to promote their products online.

The WhatsApp Business application can help small, medium, and micro businesses to market their products. Especially in the digital era, the competition is getting more challenging, the speed of information and services is very much needed.

Whatsapp Business has 5 (five) main functions that can maximize the development of MSMEs; (1) product library catalog provided, (2) shopping cart for customers when they like a product that can be included as an item of interest, (3) Set up automated messages to provide quick responses to welcome new customers, (4) Quick replies to save the general inquiry message format, and (5) Bookmark messages for easy discovery.

\section{AUTHORS' CONTRIBUTIONS}

All authors fully contribute starting from the preparation of topics, research data, and review of research results

\section{ACKNOWLEDGMENT}

The author teams are gratefull to ICESEBE Comitee and Makasar State University (UNM).

\section{REFERENCES}

[1] Abduh, T., \& Mamma, B. B. (2017). Pengaruh Dukungan Distributor Adaptasi Harga dan Strategi Internasionalisasi Terhadap Kinerja Ekspor Usaha Mikro Kecil dan Menengah (Umkm) dalam Situasi Turbulensi Pasar di Kota Makassar. Economics Bosowa, 3(8), 66-78.

[2] Feni Freycinetia Fitriani. (2021, april 19). Wajib Tahu! Ini 5 Fitur Whatsapp Business untuk Dorong 
Penjualan. Retrieved from bisnis.com: https://teknologi.bisnis.com/read/20210419/280/13 83244/wajib-tahu-ini-5-fitur-baru-whatsappbusiness-untuk-dorong-penjualan

[3] Nurmalia, L., Roshonah, A. F., Sholehuddin, S., \& Zulfa, U. (2021, February). Upaya Meningkatkan Perekonomian Warga Durenseribu Depok dalam Menggunakan Aplikasi Wahatsapp Business. In Prosiding Seminar Nasional Pengabdian Masyarakat LPPM UMJ (Vol. 1, No. 1).

[4] Oktaviani, F., \& Rustandi, D. (2018). Implementasi digital marketing dalam membangun brand awareness. PRofesi Humas, 3(1), 1-20.

[5] Purwana, D., Rahmi, R., \& Aditya, S. (2017). Pemanfaatan Digital Marketing Bagi Usaha Mikro, Kecil, Dan Menengah (UMKM) Di Kelurahan Malaka Sari, Duren Sawit. Jurnal Pemberdayaan Masyarakat Madani (JPMM), 1(1), 1-17.

[6] Suci, Y. R. (2017). Perkembangan UMKM (Usaha mikro kecil dan menengah) di Indonesia. Jurnal Ilmiah Cano Ekonomos, 6(1), 51-58.

[7] Yusuf. (2020, agustus 26). Whatsapp Business dengan Kelebihan dan Kekurangannya. Retrieved from belajardm: https://belajardm.com/whatsapp-business/

[8] Sulaksono, J. (2020). Peranan Digital Marketing Bagi Usaha Mikro, Kecil, Dan Menengah (UMKM) Desa Tales Kabupaten Kediri. Generation Journal, 4(1), 41-47.

[9] Syam, A., \& Sudarmi, S. (2019). Analysis of Student Entrepreneurship decision making in the Learning Prerspective. Jurnal Ad'ministrare, 6(1), 51-60.

[10] Wati, A. P., Martha, J. A., \& Indrawati, A. (2020). Peningkatan Keterampilan Pemasaran Melalui Pelatihan Whatsapp Business Pada UMKM. Dedication: Jurnal Pengabdian Masyarakat, 4(2), 137-148. 